Notre Dame Law School

NDLScholarship

Natural Law Forum

$1-1-1967$

\title{
The Hermeneutic Function of the Principle of Double Effect
}

Peter Knauer

Follow this and additional works at: http://scholarship.law.nd.edu/nd_naturallaw_forum Part of the Law Commons

\section{Recommended Citation}

Knauer, Peter, "The Hermeneutic Function of the Principle of Double Effect" (1967). Natural Law Forum. Paper 127. http://scholarship.law.nd.edu/nd_naturallaw_forum/127

This Article is brought to you for free and open access by NDLScholarship. It has been accepted for inclusion in Natural Law Forum by an authorized administrator of NDLScholarship. For more information, please contact lawdr@nd.edu. 


\section{THE HER MENEUTIC FUNGTION OF THE PRINCIPLE OF DOUBLE EFFECT*}

\section{Peter Knauer}

The principle of double effect leads a marginal existence in the handbooks of moral theology and appears useful only in making possible a species of hairsplitting. It is, in reality, the fundamental principle of all morality. It responds to the question whether the causing or permitting of an injury is morally evil. I speak of its hermeneutic function because the principle of double effect enables one to grasp - much more effectively than usually happens in traditional ethics - the meaning of the fundamental concepts of traditional morality in their interrelation in the tradition itself.

\section{Presuppostrtons}

How does man recognize whether an act is morally good? Traditionally, the morally good has been determined in three distinct ways: Either it is that which "orders man to his last end, that is, God." Or it is that which "corresponds to human nature." Or it is "the simply good."

The first definition is pious but it remains, in the final analysis, abstract. It does not say what concrete acts are ordered to God. In reality an ordering to God is recognized when an act is seen as morally good in itself. This logical order is not convertible. Moreover, it may be asked whether man acts directly in relation to God.

The second definition, requiring "correspondence to human nature," is more concrete. But this formula gives a reasonable meaning only if human nature is defined as "openness to reality in general." Taken rigorously, the correspondence required is not to particular human nature but to the whole of reality. ${ }^{1}$ But the formula remains still ambiguous. It does not yet reflect the distinction between physical and moral evil. In fact, a physical evil, such

\footnotetext{
* The first form of this essay appeared in 87 Nouvelle Revue Théologique 356-76 (1965) : La détermination du bien et du mal moral par le principe du double effet. In 15. Theology Digest 100-105 (1967), a resumé was published as "The Principle of the Double Effect." The present text represents a further reworking of my article, Das rechtverstandene Prinzip von der Doppelwirkung als Grundnorm jeder Gewissensentscheidung, 57 Theologie UND GLAUBE 107-33 (1967). The final text has been translated from the German by John T. Noonan, Jr.

1 The concept of nature in ethics does not mean a discoverable and unchangeable particular nature-for example, the nature of man in contrast to that of horses; but according to its origin in Greek philosophy, the concept is a counterconcept to positive
} 
as a sickness or an error or any injury, is not yet in contradiction to nature in a moral sense; such an evil is not a moral evil, even if moral evil is definable only in relation to it.

The most exact is the third definition, according to which the morally good is "the simply good." By "good" is here meant nothing other than the physical goodness of any reality whatsoever, that goodness by which something becomes desirable in any sense, according to the axiom ens et bonum convertuntur. What is "simply" good, and therefore morally good, is such a value, if it is willed in such a way that the physical evil possibly associated with it remains objectively beyond the intention of the person willing. Then the good alone, that is, "the simply good," determines the intention.

What is physical evil is known by everyone from experience. Sickness or error or other destruction is never willed for itself but only on account of some other associated good. The question is whether, by reason of this good, the permission or causing of the evil is justified or not. The unjustified permission or causing of evil signifies simply that the evil itself is also intended; then, by intention, the act becomes morally evil.

The principle of double effect, rightly understood, responds to the question whether in a given case the permission or causing of evil is justified or not. In answering this question it reveals itself as a principle which provides the criterion for every moral judgment.

Moral evil, I contend, consists in the last analysis in the permission or causing of a physical evil which is not justified by a commensurate reason. Not every permission or causing of physical evil is a moral evil, but every moral evil depends on the permission or causing of physical evil. This relation, of course, as far as cooperation in the sins of others is concerned, is direct.

It is essential now to come to a more exact understanding of the proper meaning in ethics of "commensurate reason."

\section{An Old Formulation and a Modern One}

1. The Principle of double effect appears to have been first formulated by Thomas Aquinas. ${ }^{2} \mathrm{He}$ argues for the permissibility of self-defense by force in the following way:

human determination (thus physis is opposition to thesis). It is a human determination that traffic should not move on the left but on the right. This arbitrary determination stems from a necessity arising from "nature" that for the safety of participants in traffic some fixed order be determined. Cf. for the concept of the law of nature the very perceptive article of P. Antoine, Conscience et loi naturelle, 317 ETudes 162-83 (1963).

2 Cf. J. T. Mangan, An Historical Analysis of the Principle of Double Effect, 10 Treological Studies 41-61 (1949). There is no substantial foundation for the criticism of Mangan's conclusions by J. Ghoos, L'Acte à double effet-Etude de théologie positive 27 Ephemerides Theologicar Lovanienses $30-52$ (esp. p. 31f.) (1951). 
I reply that it must be said that nothing prevents there being two effects of one act, of which one effect alone would be in the intention and the other would be beyond intention. But moral acts receive their species according to what is intended, not from what is beyond intention, since the latter is accidental as appears from what has been said above.

Therefore, from the act of someone defending himself a double effect can follow: one is the preservation of his own life, the other is the killing of the attacker. An act of this kind in which the preservation of one's own life is intended does not have the character of the unlawful, since it is natural for everyone to preserve himself in his being as far as he can.

But some act arising from a good intention can be made unlawful if it is not proportionate to the end. And so, if someone in defending his own life uses greater violence than is necessary, it will be unlawful. But if he moderately repels violence, it will be a lawful defense. ${ }^{3}$

It must first be noted that the concept of "effect" is not used here as a correlative to "cause," but in a more general sense; "aspect" might be a more exact term. It is evident that the good effect of the act in this example is itself the internal object of the act; the effect here is not different from this object as elsewhere the effect from its cause.

In the interpretation of the text it is also important to pay attention to the third paragraph, where in reality the only one possibility of a moral offense is noted. Thomas does not use the criterion of "correspondence to nature." The approach taken is this: In sinning, man seeks a real good, but his act in its total existential entirety is not proportioned to this good. Then the evil arising thereby, whether it is desired or not, belongs objectively to the act and is objectively what is "intended."

In the text of Thomas the expression "what is intended" provides the most matter for consideration. The concept of intention in ethics evidently means something different from what it means in psychology. In ethics an injury can be "intended" even if the person acting would have preferred its absence or was not thinking much about it. Conversely, as in the killing of an aggressor, an effect can be beyond moral intention, although the person acting was psychologically concentrated on it.

3 Thomas Aguinas, Summa theologiae, II-II, q.64, a.7 in corpore;

Respondeo dicendum quod nihil prohibet unius actus esse duos effectus, quorum alter solum sit in intentione, alius vero sit praeter intentionem. Morales autem actus recipiunt speciem secundum id quod intenditur, non autem ab eo quod est praeter intentionem, cum sit per accidens, ut ex supra dictis patet. Ex actu igitur alicuius seipsum defendentis duplex effectus sequi potest: unus quidem conservatio propriae vitae; alius autem occisio invadentis. Actus igitur huiusmodi ex hoc quod intenditur conservatio propriae vitae, non habet rationem illiciti: cum hoc sit cuilibet naturale quod se conservet in esse quantum potest. Potest tamen aliquis actus ex bona intentione proveniens illicitus reddi si non sit proportionatus fini. Et ideo si aliquis ad defendendum propriam vitam utatur maiori violentia quam oporteat, erit illicitum. $\mathrm{Si}$ vero moderate violentiam repellat, erit licita defensio. 
Several other relevant points should be observed in reference to the traditional teaching on "the sources of morality" (fontes moralitatis). According to what St. Thomas says elsewhere, moral acts are "determined" by the end of the act, by the finis operis. 4 In the present text he says that moral acts are determined by "what is intended." At first glance it seems surprising to say that what must be meant here is not the "end of the person acting" (finis operantis) but the "end of the work" (finis operis). Yet in order to avoid contradiction with the passages elsewhere, the "end of the act" must mean "what is intended." What results from taking this approach?

By finis operis there should not be understood - as unfortunately often happens - only the external effect, the effect that could be photographed. In ethics, finis operis means the act which is willed and intended as such. The classic example in the manuals runs as follows: Someone giving alms has as finis operis the relief of the needs of a poor man. ${ }^{5}$ But almsgiving is not merely a physical act. It becomes a moral act through the intention of the donor. The external action consists in money going from one hand to another. Is this action payment for a purchase or the giving of a present? Is it money lent to the other? Is it the repayment of a debt? Is it a bribe? Whatever in fact the action is depends on what the person transferring the money wills the action objectively to be. That is not a matter of his arbitrary declaration but of his actual intent. All physical evils which are not justified, and which arise in the pursuit of a value, are in the moral sense eo ipso morally intended and belong to the finis operis itself.

The finis operantis, which is regarded as a second "source of morality," is not to be identified merely with the moral intention of the person acting By finis operantis, the external end, there is meant the act towards which the person acting relates his first action. Thus someone may give alms in order to obtain a tax advantage. The finis operantis of the first act is related to,

Id. at I-IIe; q.1, a.3; q.18, a.2-7. The finis operis is identical with the moral object of an act.

5 E.g., M. Zalba, 1 Theologiae moralis compendum (Madrid, 1958), n. 10: "Finis ... dividitur in: a) OPERIS (intrinsecum), ad quem res vel actio objective ex natura sua ordinatur (obiectum morale actionis) in morali hominum existimatione; . . . Sic eleemosyna ordinatur ex se ad subveniendum pauperi." See also A. Vermeerscr, 1 Theologiaz moralis principia-Responsa-consilia (Rome; - 1926), n. 115: "Finis est id propter quod aliquid fit. Rationem autem agendi habere, proprium est entis rationalis. Quare finis dicitur primus in intentione; nihil magis voluntarium est, ac proin nihil magis morale. Finis operis seu internus, intrinsecus dicitur, ad quem opus per se, seu natura sua in morali existimatione tendit, ut v.g. internus finis eleemosynae est levamen indigentiae." The moralis existimatio commonly spoken of by moralists in their definition of finis operis does not mean a kind of vague judgment according to common sense, but a moral judgment of the act-a judgment which includes a reference to the intention and thereby an implicit application of the principle of double effect as it has been above interpreted. 
and is indeed identical with, the finis operis of this second act. If someone performs a single act without relating it to another act, he has only a finis operis of his act, and, to speak exactly, there is no finis operantis. ${ }^{6}$

In addition to the finis operis and the finis operantis, another traditional source of morality is the circumstances of an act. Their only function is to determine the act quantitatively. A theft is a theft according to the finis operis whether the amount stolen is large or small; but the gravity of the offense deperids on the amount. If the theft is connected with breaking and entering, then this fact is not the addition of another circumstance but a change in the finis operis itself. 7

The division of finis operis and finis operantis into an external physical act and an internal intention cannot be maintained in one and the same act; this is an arbitrary distinction arising on Cartesian foundations. Neither the pure external happening nor the psychological intention is morally understandable alone; only the objective relation, in which both have a part, is understandable. This conclusion means that the moral species of the finis operis depends on whether this relation is one of correspondence or one of final contradiction, while the finis operantis relates to the finis operis of another act.

For the time being I will rest with this formal definition of finis in ethics; at a later point I shall return to the topic to give a more exact definition.

2. Today the principle of double effect is most briefly formulated as follows:

One may permit the evil effect of his act only if this is not intended in itself but is indirect and justified by a commensurate reason.

The modern formula seems to be different in more than one respect from that of St. Thomas. He required the act to correspond to its end (actus sit proportionatus fini). The present formula speaks of a "commensurate reason" (ratio proportionata). The principle of double effect is, I believe, rightly understood if it is recognized that in fact both requirements mean the same thing.

Thomas also held that the evil might not be effected directly. According to him, the intention must be accidental (per accidens); it must be beyond intention (praeter intentionem). The usual explanation of this terminology

- Cf. A. van Rijen, Daden met meerdere gevolgen en de leer over de bronnen der zedelijkheid, in JaArboex 1960 van het Werkognootschap van Kath. Theol. In Nederland 48-82 (esp. p. 70) (Hilversum, 1961); similarly, F. D'Hoogh, Over de afzonderlijke zedelijke handeling, 50 Collectanea Mrghiminnsla 336-53; 476-96 (especially p: 486) (1965), which refers to my first article cited in the asterisked footnote.

${ }^{7}$ Cf. Thomas, op. cit. supra note 3 , at I-II, q.18, a.10; q.88, a.5. 
understands the pair of concepts, "direct - indirect," in the sense of direct or indirect physical causality; but this explanation is questionable. I say that an evil effect is not "directly intended" only if there is a "commensurate ground" for its permission or causation. There are not two distinct requirements when I speak of the "indirect causing" of evil and of "a commensurate reason" for the act. The principle may be adequately formulated as follows: One may permit the evil effect of his act only if he has a commensurate reason for it.

The objectivity of all ethics depends on the determination of commensurate. A "commensurate reason" is not an arbitrary X, equivalent to "serious reason in the circumstances." The customary deformed understanding of this concept identifies "commensurate" with "serious"; from this deformation, an unhealthy confusion in ethics has resulted. These observations must suffice for now; I shall return later. to attempt further clarification.

\section{The Same Principle in a Variety of Expressions}

THE KEY concept in the modern formulation of the principle of double effect is the requirement of a "commensurate reason." This concept can be found in various other chapters of traditional ethics: "Cooperation in the Sin of Another," "Intrinsic Malice and Extrinsic Malice," "Affirmative and Negative Laws of Nature." In scholastic ethics all of these articles were put in different drawers. But in each there is rediscovered the structure of the principle of double effect: the causing or permitting of a physical evil is morally permitted because of a commensurate reason; without a commensurate reason the act is morally evil.

1. "Formal" cooperation in the sin of another is absolutely forbidden in every case. "Material" cooperation is permitted if there is a commensurate reason. ${ }^{8}$ If a commensurate reason is lacking, material cooperation in the sin of another becomes formal and therefore forbidden. The absence of a commensurate reason is decisive.

It is evident that the permission or causing of evil on behalf of another becomes moral evil only through the application of the principle of double

\footnotetext{
${ }^{8}$ Here it must be observed that the pair of concepts, "formal"- "material," in the teaching on cooperation with evil is used in a different sense than in the distinction made between "formal" and "material" sin. In a material sin the person acting is in good faith as to the objective permissibility of what he does. For example, he gives his friend candy when in reality it is poison. In formal sin there is complete consciousness of the actual character of transgression in the act, and therefore the person acting is guilty. In the sense in which the terms are used in reference to cooperation, there can be complete consciousness of what one is doing and nonetheless the act may be material cooperation and not formal cooperation.
} 
effect. If I have a commensurate reason for permitting or cooperating with the evil, the evil remains indirect for me. I only participate materially therein, while the formal content of my act is distinct from the evil, so that my act in reality is good. But if my act lacks a commensurate reason, I directly and formally cause or permit evil on behalf of another and become guilty myself. In short, the pair of concepts, "formal" - "material," as they are used in the teaching on cooperation in the sin of another, are fundamentally the same as "direct" and "indirect" in the modern formulation of the principle of double effect.

2. There is a way of acting, which, according to the common teaching, is "intrinsically" evil and therefore universally forbidden. Other ways of acting are only "extrinsically" evil and therefore permitted in the presence of commensurate reasons. But if there is no commensurate reason, then they also are absolutely forbidden in every case. This teaching means, I maintain, that then they are "intrinsically" evil. What is intrinsically an evil act is brought about when no commensurate reason can justify the permission or causing of the extrinsic evil, that is, any given premoral physical evil or injury. This is a thesis which has special significance for contemporary ethics. It says that "morally evil" and "intrinsically evil" are synonymous expressions.

Yet, are there not acts which universally are intrinsically evil so that the question of whether there is a commensurate reason or not is simply superfluous? For example, is not murder under all circumstances forbidden? Such a judgment of universal condemnation is only reached by an implicit application of the principle of double effect. As long as an act is judged according to its external appearance and independently of the character of its reason, it is not understandable as a human act; it is not something that can yet be judged morally. Once it is determined whether or not the reason for an act is commensurate, the moral species of the act may be determined. Murder, for example, consists by definition in causing the death of a man without a commensurate ground. If the same external act, such as causing of the death of a man, has a commensurate ground, then it is from the beginning an act morally different from murder - either self-defense or a lawful act of justice in order to protect the community.

Again, the.same conclusion is reached: The terms examined are contained in the principle of double effect. The pair of concepts, "intrinsic extrinsic," signify the same thing as "direct" and "indirect" in the formulation of the principle.

There are further pairs of concepts which also stand in the same relation to the requirement of a commensurate reason. There are, for example, per se per accidens and "in intention" - "beyond intention" in the text cited from St. Thomas. The use of these different concepts for one and the same reality 
reveals that the scholastics had not reflected thoroughly enough on their meanings.

3. Especially instructive is a comparison of the principle of double effect with the traditional teaching's distinction between affirmative and negative laws of nature.

Negative laws (for example, "You shall not murder," "You shall not lie") oblige, as the manuals say, "always and everywhere." They permit no exceptions but are universally valid.

There are, however, affirmative laws corresponding to the negative laws. For example, corresponding to the instances given above, these are, "You shall revere and protect human life," "You shall speak the truth." In contrast to the negative obligations these affirmative laws only oblige "semper, sed non pro semper." A commensurate reason justifies the nonobservance of such laws. If a commensurate reason is lacking, however, no justification is possible. In such a case the affirmative law becomes absolute, "semper et pro semper," exactly like the negative law.

The negative law, in fact, is already contained in the affirmative. The negative law is only the application of the affirmative in cases in which there is no commensurate reason excusing from nonobservance. The pure nonobservance of the affirmative law is already identical with active infraction of its negative form. A permission of evil which is not justified by a commensurate reason amounts morally to positively causing it. The physical distinction between these cases is very secondary for moral judgment. It is only the more exact specification of the behavior which depends on this ground for example, when we want to distinguish between homicide and murder.

But the affirmative laws go further than the negative laws in their power of obligation. The sphere where their application is unconditioned is identical with that of the negative laws, which must always be observed if there is a lack of commensurate reason. The "semper" of the affirmative laws is to be observed without restriction. But attention is to be given them even when a commensurate reason permits their present nonobservance.

What do I mean by this? I will give a medical decision as an example. There is a therapy against cancer based on present knowledge of the cells, a therapy which produces disturbances in the blood. To cause such disturbance without commensurate reason would be an injury to the health of the patient and so an intrinsically evil violation of negative law. But if such therapy holds the promise of improvement in the total health of the patient, the physician permissibly accepts in exchange the unavoidable evils which accompany it. He has a commensurate reason which makes "indirect" his action of causing an evil. His act is a justified nonobservance of the affirmative 
law which demands that he have care for the healthy state of blood in his patient. This value in his work evidently manifests an affirmative law corresponding to the negative law, but going beyond it. ${ }^{9}$ If the physician is dispensed from the direct observance of the affirmative law, it remains valid, and he may not content himself forever with the necessity which forced it not to be observed. He is obliged to seek better solutions. In this obligation the meaning of the affirmative law controls the negative. If a better therapy is developed, what has been permitted can no longer be applied.

This example also shows explicitly what in ethics is unchangeable natural law. In ethics, only the obligation to seek the best possible solutions in their total existential entirety is unchangeable. The best solutions cannot be determined in advance as in a catalogue; they must be developed within the dynamic of the affirmative obligation that there be development. In this development only the prohibition of direct permission or causing of evil is unchangeable.

Negative and affirmative precepts thus constitute still another area ruled by the principle of double effect. To the negative law there corresponds the absolute prohibition of directly causing or permitting evil in any way. To cause or permit evil indirectly is like the nonobservance of an affirmative law where this nonobservance is justified by a commensurate reason. A commensurate reason would evidently be the observance of another, more compelling affirmative law which in existing conditions could not be observed at the same time as the first law. The obligation would remain to seek the possibility of being able to observe both laws. In the principle of double effect there is a commitment to advance in all the interrelated areas of reality. ${ }^{10}$

\section{What Is a Commensurate Reason?}

I HAVE indicated that the expression "commensurate reason" determines the meaning of all the other concepts. Through lack of a commensurate reason material cooperation in sin becomes formal; extrinsic malice becomes intrinsic malice; affirmative law takes the shape of an unconditional negative. The principle of double effect means that to cause or permit an evil without

${ }^{9}$ If the principle of double effect appears purely formal in its nature and requires for the morality of an act only the presence of a commensurate reason which then makes indirect the evil accepted in exchange, yet the principle contains a content determined by ontology. Any reason whatsoever may be the reason for an act, and yet one may not conclude that any reason is in fact commensurate to the act. Conversely, the question what is evil may also be answered from ontology: it is the lack of completeness which could be present.

10 Cf. L. Janssens, Daden met meerdere gevolgen, 32 Collectanea Mechuiniensia 621-33 (esp. p. 632) (1947). 
commensurate reason is a morally bad act. The evil is no longer accidental in the intention of the person acting, but it becomes constitutive of the moral content of the act, the finis operis, or internal object. If a commensurate reason is present, the permission or causing of the evil becomes indirect and is objectively no longer the object of moral intention. The commensurate reason occupies the same area as what is directly willed and alone determines the entire moral content of the act. If the reason of an act is commensurate, it alone determines the finis operis, so that the act is morally good. The permission or causing of a physical evil is indirect or direct as there is or is not present a commensurate reason. Self-defense is a good example. The external operations are the same as those of a murder, for there is a use of deadly weapons. The moral distinction is recognized only when the unavoidable death of the attacker has a commensurate reason in self-defense. The object of the act is then the commensurate reason which consists in the preservation of one's own life against attack.

But when is the reason for an act a commensurate reason? There is a reason for every act even if it is morally evil. One can only will something on the condition that he is able to see a value in it in some aspect. The freedom of the will is grounded in this fact. Because the will by its nature is directed to the good as such, it can either will a good positively insofar as it is good or reject it insofar as it is only one good and not simply the good. The possibility of both decisions is based on the same judgment according to which the object is really a (but not the) good. ${ }^{11}$

Thus the reason for each act is an actual good: A thief steals only because he hopes for a use from the money. Even the one who acts from pure hate against the moral law seeks an actual value, although in a mistaken way. In his existential decision he wills to determine himself. But does he reach in this way what makes the freedom worth striving for?

For an act to be morally good it is not enough that it always seek a value

11 The postulation of a necessary judicium ultimo-practicum, as it is commonly assumed by the scholastics, would contradict freedom and in the last analysis make its rational explanation impossible. It is a false assumption that the fundamental form of free choice is the possibility of decision between several goods, among which one chooses that good which reason, working reciprocally with the will, declares to be the greatest. This explanation contains a logical circle which is disguised with difficulty. In reality there is a libertas specificationis not only when one compares several objects with one another, but also when one accepts or rejects a single good in itself. The first form, that is, libertas specificationis inter plura, is then only a conclusory application of the second libertas specificationis quoad idem. A No is naturally more than the pure preservation of an act of the will on the basis of a so-called libertas exercitii which under no circumstances can be designated as the fundamental form of the freedom of the will. I make this observation only because I know of no other satisfactory explanation of the freedom of the will in scholasticism. 
and so always have a reason. What is required is that this reason be commensurate. What does this mean? "Commensurate" to what?

This question is commonly answered in this way: The good achieved must correspond to the evil accepted in exchange, and indeed the good must outweigh the evil. But this answer is no advance. Such a quantitative comparison is not possible, as it is a matter of qualitatively different values which cannot be compared with one another. When some years ago in Germany the speed limit in city traffic was experimentally abolished, the death toll in traffic accidents rose threefold, and therefore the fifty-kilometer limit was very soon restored; but the death toll was still quite high. Could the loss in human life be compared with the advantages which a speedier traffic system brings? The different values which are measurable by themselves are incommensurable with each other. There is no common measure for them.

A comparison becomes possible if it is established what function one value has for another. A faster traffic causes a loss of more human lives. But if there were no traffic, the preservation of life as a whole surely would not be greater. The preservation of life in great part depends on a sound economy, which, in turn, today depends on the fastest possible traffic. Thus the complete throttling of traffic would not serve the preservation of human life as a whole. By this standard, this end would not be a commensurate reason. At the same time, faster traffic is a greater good the more it is accompanied by safety. This valuation rests on the foundation that the value sought is commensurate when it is achieved in the highest possible measure for the whole.

The example of traffic is instructive in another aspect. Speed limits, regulation of automobiles, and other limits on the freedom of individuals serve in fact to produce faster traffic and greater safety in relation to the whole. The limitations of freedom directly serve to achieve the greatest possible freedom for the whole. The violator of traffic rules contradicts the value as a whole which he wishes to realize for himself. There is a contradiction between his deed and its foundation.

A student may desire to learn the most possible. He can be successful in this pursuit only if he interrupts his work from time to time. If he is so bent on his objective of learning that he injures his own health, perhaps for a short time he may achieve something above average but the result on the whole will be less. In an extreme case he becomes sick from overwork and cannot accomplish anything. Then in the last analysis he contradicts his own purpose. Something similar happens in any immoral act. An objective is sought which has an appropriate price (tantum-quantum), but it is sought at any price. In unmeasured desire there is sacrificed what 
alone would assure the greatest possible achievement of the end.

The government of a developing country has a plan to better the living standard of its people. This objective may be reached only through an ongoing industrialization which requires an extensive renunciation of immediate accomplishments. If, instead of such a program, the administration forces immediate sharing of goods by use of the police, it may indeed achieve an elevation of the living standard. But this approach quickly leads to a destruction of the economy, and the need becomes greater than before. In seeking an immediate achievement of the objective there has been a neglect of the total conditions of possibility and thereby a contradiction of the objective itself. In this example there is especially clear what could be called the feedback effect or the reciprocal function of two values. On one hand, a rise in the living standard requires industrialization. Industrialization is not a higher value than a better living standard - the possibility of such a comparison has already been denied - but industrialization is of the greatest urgency if a higher living standard is to be achieved. On the other hand, industrialization cannot be achieved if at the same time there is not at least some beginning of a rise in the living standard, because no industry can be developed with hungry workers.

All of these examples may illustrate that unintelligent and therefore immoral acts are in the last analysis self-contradictions and consist in unmeasured desire taking the fruit from the tree before it is ripe. There is an isolation of the objective from its proper conditions. A good is sought while the conditions for the highest possible realization of the good are abandoned. This state of affairs is described by the language of the old moral theology when it singles out an immoral act as an act against nature, contra naturam. There is a destruction of reality itself when part of reality is isolated from its interrelations. If someone pays a price for a good which is not commensurate with the good but, rather, contradicts it and makes the highest possible achievement of the good as a whole impossible, he irresponsibly causes injury. When the expression contra naturam is used in ethics, there is not meant physical evil which is against nature only in a premoral, physical sense. What is meant is a physical evil caused or permitted without commensurate reason - that is, in this act there is a long-run contradiction in reality between the value sought and the way of achieving it.

Immediately in the short run there may often be a remarkable achievement. Irrationality. first emerges when consideration is given to all the interrelationships and when it is asked if the objective existentially achieved, seen in terms of the whole, best corresponds not only to a particular person but to the totality. What this distinction between individual and totality 
means may be clarified by the example given above of freedom in traffic. The moral consciousness poses this universalizing question. The distinction between the two approaches is rigorously objective. Whether a reason for an act is commensurate or not is beyond all subjective arbitrariness. ${ }^{12}$ The reason for an act is not a commensurate reason if there is a contradiction in the last analysis between the act and the reason.

A similar result is reached if the modern formulation of the principle of double effect is compared with the formulation of St. Thomas. As I noted earlier, Thomas instead of requiring a commensurate reason (ratio proportionata) says that the entire act must correspond to its end (actus sit proportionatus fini); but end means nothing other than reason for the act. It is simply a matter of a correspondence between the act and its proper reason. Both requirements, that the reason for an act be commensurate (that is, that it be one commensurate to the act itself) or that the act must correspond to its reason, mean the same. An act becomes immoral when it is contradictory to the fullest achievement of its own end in relation to the whole of reality. A short-run "more" of the value is paid by a "lesser" achievement of the same value in the long run.

\section{Three Different Meanings of "End"}

So FAR I have used the expression "end" (for which "intention" could be substituted) in an entirely specific sense as identical with reason. It is important to note this in order to avoid an easy misunderstanding. "End" can also have another meaning and simply signify a determinate concrete fact. Thus a band of bank robbers has the end of entering the treasury of a bank. It would be absurd to measure the morality of this act by asking if the band is using the most appropriate means of achieving its end. Such a determination is not meant when I speak of the correspondence required

\footnotetext{
12 R. A. McCormick, Notes on Moral Theology, 26 Theological Studies 603-608 (1965) has raised as an objection to my French article mentioned at the beginning of the notes that my explanation of the principle of double effect transgresses the boundaries of an objective ethics. Unfortunately in his account of my work he first confuses "commensurate reason" with any reason ("The formality under which the act is willed is determined by the proportionate reason for acting," p. 604) and then confuses it with a "reason proportionate to the original goal" (p. 604); and he appears to conclude, contrary to my express statement, that any direct quantitative comparison of one value with another value may create a commensurate reason (p. 606). Above all McCormick objects that I failed to distinguish in my article between "inner" and "outer" "commensurate reasons." In reality I had set out this distinction on pages 360-61 as the distinction between finis operis and finis operantis. I return to it in Part VII of the present paper. His chief objection is that "this reasoning would destroy the concept of that which is intrinsically evil ex obiecto" (p. 605). What I have said in Part III.2 above is a response to this objection. What was lacking in my French article was a failure to make explicit the identity of the morally evil and the intrinsically evil, that is, the evil ex obiecto. On this account I am grateful to McCormick for his criticism.
} 
between the act and its proper end. In this requirement what is meant by end is not a concrete fact but what in a particular fact makes it worth acting for, its ratio boni. In the sense $I$ use it, in which the end of an act is identical with its reason, it must be said that the value the robber band is seeking is to become rich. At this level the question is posed whether breaking and entering leads in the long run to the greatest realization of riches as a whole or whether it is in contradiction to such realization.

If end is used as identical with reason, it is still not a concept of ethics. As I have already shown, both good and bad acts have a reason in this sense, as reason means a value. The reason of the worst act is never an evil but always a good, that is, something in fact worth striving for. Therefore, a source of morality is not reached when reason or end in this sense is reached.

In a moral sense the end of an act is what is "intended" - the finis operis and, eventually more broadly, the finis operantis, the ordering of the act to the finis operis of a more comprehensive act. These expressions signify the reason of the act insofar as it is in correspondence with the totality of the act or not. In this moral sense, the reason is no longer considered alone but in its relation to the act itself. If the reason of an act is a commensurate reason, it is in a moral sense the end of the act and intended. It is then completely identical with the finis operis, so that the eventual concomitant evil, even if it is considered necessarily part of the exchange, falls outside the finis operis. The finis operis of the act is, then, simply good.

When the reason of an act is not a commensurate reason so that between it and the act in terms of the horizon of the whole reality there is a contradiction, the reason in itself may be as good and as important as possible, yet the finis operis of the act is no longer constituted by this reason; the reason is in contradiction to the act, and the finis operis is constituted by the evil effect which accompanies it. In the example of bank robbery, the chief evil effect is the harming of other people in the taking of their property. This harm is intended in the moral sense in a bank robbery, although the gangsters have only their own enrichment in view.

In Part VIII I shall return to the threefold meaning of the concept of end in a discussion of the distinction between mutilation and medically necessary amputation.

\section{The Moral Good as the Best Possible}

Every human act brings evil effects with it. The choice of a value always means concretely that there is denial of another value which must be given as a price in exchange. If the chosen value is sought in its entirety in a com- 
mensurate way, the evil falls outside what is directly willed. In other cases when the reason of the act is not commensurate, the evils which arise are themselves directly willed even if they are not in the least desired in themselves.

I shall seek to make the matter still clearer through the development of a statement of Aristotelian ethic. I refer to an easily understood alternative to the scholastic procedure. According to Aristotle, morally right behavior is a mean between two extremes which can be recognized as too much or too little. It is observed that in consideration of the good, the mean itself is an extreme.13 Thus, for example, bravery is a mean between foolhardiness and cowardice. Aristotle declared that bravery appears more closely related to one of the two extremes, foolhardiness. This observation, which is made by Aristotle himself with some surprise, provides an opportunity for asking whether there is not also a name for right behavior which appears to lie closer to cowardice, the other false extreme. There is, in fact, prudence. It belongs inseparably with bravery. It is clear to everyone that bravery without prudence is in reality not bravery but foolhardiness; prudence without bravery is in reality only cowardice. If foolhardiness consists in too great a risk so that in the end too little is achieved, bravery consists in achieving the most possible of that for which the entire risk is undertaken. Again, there is the criterion of commensurate reason; that is, of a proportionality of the act to its proper objective. Bravery is readiness for any risk which is justified by the end in its existential entirety. Bravery is thus accompanied by prudence, which holds the risk to the smallest degree possible so that the greatest possible gain may be achieved. Cowardice lacks this measure. It wagers the least, but thereby loses too much of the whole.

The formal structure of winning and losing which is implied in this example is founded on the principle of double effect. Evil may be accepted in exchange if, in relation to the whole, the smallest possible evil is exchanged for the highest possible gain. The whole is the determinative point of view for morality; it distinguishes ethics from a technique based on experience in a particular area. When an act neither sacrifices too much nor gains too little, there is conduct which is commensurate to the end sought. Immoral acts consist in preferring the success of the moment to true gain and thereby spoiling the achievement of true gain in the act which is carried out. A coward naturally always says that he is prudent, and a fool often holds himself to be brave. They both refer to their good intentions, but they are both unmasked when consideration is given to the complementary virtue. Where is the bravery in the pretended prudence of a coward? Where is the prudence in the asserted

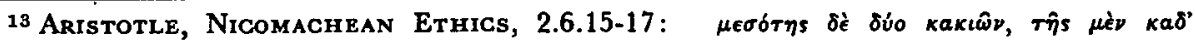

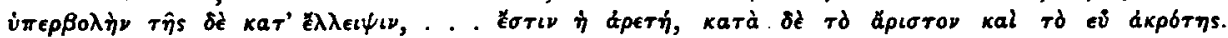


bravery of the fool? In the presence of the complementary virtue there is recognized that the act has a commensurate reason; that is, it is recognized that the act is in proportion to its end. Liberality accompanied by economy is distinguished from extravagance; economy is only avarice unless it is liberal. Progress is not a pure seeking of what is new but a preservation of what is good in the old; there is in fidelity to tradition only a spiritless severity unless it fosters the creation of the new. Zeal and discretion go together; otherwise zeal in reality becomes fanaticism, and instead of discretion there is mediocrity. "Be wise as the serpent and simple as the dove" (Matthew 10.16). Such a demand is not paradoxical but excludes slyness and stupidity together. Christian hope works out its salvation "in fear and trembling" (Philip. 2.12) ; one without the other is either presumption or despair. There are many other examples. This square is of universal applicability.

Moral good consists in the best possible realization of any particular value envisaged in its entirety. This assertion is fundamentally different from the rigorist thesis which says that among different goods the highest must be always chosen. Here, rather, there is freedom as long as the particular value chosen is not itself subverted.

A particularly good example is the problem of the vocation where the choice has to be made between several morally good possibilities. A false model of this choice is provided if vocation is understood as "a specific call which God himself has implanted in me in advance." The will of God which is knowable objectively consists in being able to decide for oneself among different good possibilities. A so-called vocation should not be understood objectively as an advance determination to one possibility. Vocation consists rather in the possibility of having appropriate motives for the way to be chosen. This is the grace of a calling. It is completely possible that someone be called in this sense to different vocations, so that he himself must make the actual choice. Only in an unusual case where there is an extraordinary need can there be an obligation which is binding in one direction from the beginning; in such a case any other choice would be self-contradictory, because the other possibilities depend for their realization on a condition which must be realized at any cost.

\section{Bad Means}

The explanation. I have given to this point of the principle of double effect is very different from the usual explanation given in the teaching on what is voluntarium in causa. This is usually given the following sense: If an evil is the further physical consequence of the good which is willed, or at least does 
not precede the good which is willed, then the permissibility of the act depends on what is intended by the act. If the evil permitted or caused accompanies the good to be achieved only as a consequence or a concomitant, the act is permitted; otherwise not. But if the evil physically precedes the willed good and so is "the means" to its achievement, then it is directly willed and makes the entire act evil, just as if the evil was intended by the act. In this case, the principle of double effect is replaced by another principle: A good end does not justify bad means.

Such a contrast between these two principles involves a logical error. In the principle that the good end does not justify the bad means it is already assumed that the means are morally bad. ${ }^{14}$ The principle is only applicable if the moral judgment has already been formed; in the moral evil of the means something new is not discovered; the evil was already established. In the principle of double effect, in contrast, a moral judgment of this kind is in the process of being determined. The two principles are not parallel in their applicability. That a means is morally bad signifies in our sense that the reason for the application of the means is not commensurate. The pure determination that the means entails physical evil is not enough to qualify it as morally evil. It may well be that the permission or causing of this evil is only indirect because of a commensurate reason. Provided that an end is sought in its existential entirety in a truly commensurate way, the means determined by this end which can contribute to the best possible realization of the end may justify accepting physical evil in exchange. Of course, one must be satisfied that this price is the smallest possible. In this sense the axiom is valid: Finis determinat media.

The principle that the good end does not justify the bad means may rightly be understood in either of the two following senses. On the one hand, it may be a matter of a single act whose reason is a good end. The principle asserts that this end, however serious and good in itself, cannot justify the permission or causing of physical evil in the course of its achievement if it is not a commensurate reason in the sense $I$ have indicated. The act must correspond to the value sought not only in the short run but in its existential entirety. On the other hand, the means may itself consist in a proper act which can be recognized without reference to a further objective as having a reason in itself which suffices for the positing of the act. If this reason is not a commensurate one, then the act may not be morally saved, even if it can be related to another act which is an achievement of an end that in itself is good. The means in the last analysis would contradict the act.

14 Cf. F. D'Hoogh, op. cit. supra note 6, at 487. 
In the second sense, St. Thomas says at the conclusion of his analysis of self-defense that it is not permitted to will the death of the aggressor as an act in itself. ${ }^{15}$ Self-defense then would be the finis operantis and no longer the finis operis. The death of the attacker would be willed even if it were not determined to be necessary in fact for self-defense. Such an act would obviously not be permissible.

But clearly there are cases in which the causing or permitting of an evil precedes the achievement of the end without the act thereby becoming morally bad. The evil is justified by a commensurate reason; although the cause is physically direct, it is not direct in a moral sense. The following example is classic. A dangerous fortress may be made harmless only by being stormed by force, but in the outer bastion of the fortress there are innocent hostages who will lose their lives before the proper end of the action, the storming of the fortress, can be achieved. In traditional ethics this action is permissible as long as there is no other way to avoid the evil. The decisive question is not whether the evil, the deaths of the prisoners during the storming, follows the good which is sought or precedes it; the decisive question is in what way the evil is willed. The act is morally bad if the evil is direct or formal, that is, if the act is willed in such a way that there is no commensurate reason for it and therefore is irresponsible. The purely physical series of events is irrelevant to the moral qualification of good or bad. One and the same means can in one aspect be a value or lead to the realization of a value and simultaneously be a physical evil in another aspect. If there is a commensurate reason for the permitting or causing of the evil, the means is effectively willed only in its good aspect. The effect or, more exactly, the aspect which is physically evil remains morally outside of what is intended.

When the categories direct and indirect are confused with purely physical categories, a blind hairsplitting is introduced into ethics. Removal of a cancerous uterus is permitted even though as a consequence the fetus within the uterus loses its life. But to remove only the fetus, because the uterus may still be healed, is said by some theologians to be murder; they think the death of the fetus is used as a means and so is directly willed. In other words, a solution which includes both the death of the fetus and the removal of the entire uterus with consequent sterility is said to be better than that the fetus alone lose its life. Who can understand this?

In the case of an ectopic pregnancy it is almost certain that the woman together with an unborn child will die if the fetus is not removed as early as possible. The "insight" that this is immoral is scarcely demonstrable to any

15 ". . . illicitum est, quod homo intendat occidere hominem, ut seipsum defendat . . ." 
doctor. It is agreed that direct killing is forbidden. But in my opinion, some scholastic moralists have assumed incorrectly that the saving of the mother, which in the normal case is probable if there is immediate removal of the ectopic fetus, is a direct killing. Negative laws (You shall not kill, You shall not speak an untruth, You shall not take the property of another) are understandable only as the prohibition of direct and therefore formal permission or causing of these physical evils (death, error, loss of property, etc.), in cases where by definition there is no commensurate reason. Whether there is a violation of a commandment (that is, whether an act is murder, lying, theft) can be ascertained only if it is established that the reason for the act in its existential entirety is not commensurate. Without a commensurate reason an evil is always willed directly, even if attention is not expressly directed to the evil but it is desired that there be no such evil.

\section{Exceptions in Ethics}

IN THE recent literature of moral theology there has been evoked from time to time what is called the principle of totality, a principle contrasted with the principle of double effect. The latter is said to relate only to the justification of the "barely permissible," while the principle of totality relates to the "justification of an effect willed for itself by reason of its connection with the whole order of purposes and goods." 16 The principle of totality justifies an act such as the removal of a sick organ in order to save the whole organism.

In my opinion the principle of totality is in reality not distinguishable from the principle of double effect. The latter bears not merely on the passive permission of an evil but relates to the most active kind of permission; concretely the act itself may cause or effect the evil; the evil is not direct unless it is willed without commensurate reason. In fact, it is not true, for example, that a medically necessary amputation is willed in the moral sense as a removal of an organ. What is willed is only the removal of what is an obstacle to health in its entirety. That this obstacle is identical with the hitherto useful member of the body is accidental for moral judgment (existimatio moralis), ${ }^{17}$ because a commensurate reason justifies the acceptance of the loss. For the eventual preservation of the organs the existence of the person itself must certainly first be assured. There is not a quantitative relation between a part to the whole, but a priority of dependence of one upon the other. If there is a commensurate reason, the removal of an organ is justified, and the

\footnotetext{
${ }^{16}$ L. Liebhart, Sterilisierende Drogen, 111 Thrologsch-Prakmsche Quartalsghrupt 192 (1963).

17 See supra note 5.
} 
operation is not the mutilation of the organism, which is always impermissible.

The example may also serve to clarify the distinction I have already made between the three meanings of "end." In the operation the surgeon does not think of anything except the skillful removal of the limb of the patient. This removal is the concrete thing which is willed by him, and one can say that this act is "the effect willed in itself." But the morality of the act is not determined on this level. Whether the removal of a limb is a health measure or a mutilation of the patient cannot be recognized in the concrete actuality which might be photographed. The reason why the surgeon removes the limb must be looked at. What value does the act seek to serve? It is done because of the health of the patient. But this by itself does not determine the morality of the act. A purely good intention in the psychological sense does not determine the moral goodness of an act. It must be established that this reason is a commensurate one. If, in the given circumstances, the act is the best possible solution of the problem in terms of the horizon given by the whole of reality, it may be said that the act is morally good. In a moral sense, what is then intended is not the taking of the limb, but the health of the patient. That the obstacle to be removed was once a useful limb falls in a moral sense outside of what is intended and is not directly willed. It is another case if the reason for the removal is not commensurate - for example, if it would be possible to achieve the objective of health in a way which would cause less loss. The removal of the limb would then contradict the best possible achievement of the end. In such a case, in a moral sense the removal of the limb in its function as member of the body would be directly willed, even if the surgeon did not direct his attention to this aspect.

In another respect the example is instructive. In the usual thoughtless dichotomy between physical act and intention any act whatsoever might be labeled by any intention whatsoever. But this is in reality not even possible on the psychological, premoral level. Suppose that blood poisoning could be healed by the injection of a new serum so that the objective of health would not require removal of the poisoned limb; it would be logically impossible to prefer the limb's removal for the same reason as before the discovery of the serum. If a physician desired to carry out such an amputation, he would in fact do it for some other reason, e.g., the avoidance of unusually high expenses. But as to this new reason the question would again have to be asked: Is it a commensurate reason or not? In this example it is seen that the permissibility of a medically necessary amputation is not an exception to the prohibition of mutilation, but in a moral sense is an act which is not a removal of the limb but a healing of the sick.

In a similar way a series of other apparent exceptions to the moral law 
may be clarified. To return to the example of self-defense, the death of an aggressor may be caused if there is no other way to save oneself. Similarly, the lawfulness of the death penalty in traditional morality has been upheld under certain circumstances. In this case Thomas himself thinks that the death of the criminal is directly intended. ${ }^{18}$ I do not agree with his formulation. But many moralists have followed him in thinking that the commandment, You shall not kill, is to be understood in a restrictive sense admitting certain exceptions: The guilty may be killed, and an unjust aggressor has already given up his right to life. This analysis is not persuasive. First, one may repel the aggression of an insane man although he is incapable of a moral act and therefore completely incapable of a guilty deed. Conversely, one may not kill an aggressor, however unjust, if in other ways one can save oneself and other possible victims. It is false that a criminal condemned to death has no right to life. How else explain that it is murder if one on his own authority shoots a man on his way to execution?19 The execution of the judgment of death is not direct killing, and so not murder, because there is no other reasonable possibility of self-defense for the human community. Then the finis operis of the execution is only the self-defense of the community. I do not thereby contend that one can be satisfied for all time with this solution. The obligation remains to seek better solutions within the realm of the reasonably possible. That in a certain historical situation the death penalty was rightly judged permissible does not indicate that it remains fundamentally and absolutely permissible.

If someone in extreme necessity takes the property of another because it is necessary for him to preserve his life, he does externally what a thief would do. But a theft is only the taking of the property of another without commensurate reason. A thief wills to enrich himself, but the value of possession assumes a legal order. Through the violation of this order the thief contradicts his own end in its existential entirety. The reason for his act is therefore no longer commensurate. A thief is thus guilty morally of the evil he has caused. It is different as to the poor man in extreme need for whom there is no other possibility of saving his life than the taking of the property of another. In order to be reasonable the legal order which protects property rests on the assumption that everyone has a right to life. The poor man in extreme need does not contradict his end, which is the preservation of his life; and he does not contradict it even in terms of a universal observation (and this point of view is the decisive one). Therefore he does not will directly that the former possessor lose his property and suffer injury. It seems to me false to explain

18 Tromas, op. cit. supra note 3 , at II-II, q.64, a.3 and 7.

19 See the observations of L. Bender, Ius in vita, 30 ANGelicum 50-62 (1953). 
this case by asserting that the possessor had no property right in these circumstances to his property, so that he allegedly has suffered no injury.

A lie consists in telling what is false without commensurate reason and therefore directly or formally causes the error of another; trust is expected and at the same time subverted. If such behavior were permitted, then trust in its existential entirety would be impossible; truth could not be shared. But it is something entirely different if, in order to preserve a secret, a false answer is given to an indiscreet question. Then the case is parallel with self-defense; the error of the other is not directly willed. Morally, the answer has the meaning that I will not give away my secret. That the questioner is deceived is an evil which is rightly accepted in exchange for preservation of the secret. I assume, of course, that the question of the other is illegitimate, so that he has no right to the knowledge of the fact, and I assume that in no other way can the secret be preserved. In many cases a clearly evasive answer or the attempt to use ambiguous language, assuming that one has the presence of mind to think so quickly, is entirely inadequate to protect the secret. In these circumstances a false answer instead of such language is not the same as a lie.

A concrete example will make my meaning clearer: A family in East Berlin before the building of the Wall wishes to flee to West Berlin. While it is gathering some small household effects to take to West Berlin, some neighbor remarks on its activity and asks, "Is it true that you are going to West Berlin?" The detection of such preparation for flight carries with it a serious punishment in prison in East Berlin. How can such a question be answered? If answer is evaded ("What does this matter to you?"), all is betrayed. To avoid an answer without betraying the secret, the only course is to repel with scorn the suspicion of desiring to flee. Such a response in my opinion has as little to do with lying as the death of an aggressor in the case of necessary self-defense has to do with murder. On the contrary, it would be objectively immoral to betray a secret which should rightfully be preserved.

Usually an attempt is made to solve this kind of problem of speech with a theory as to ambiguous language. But it must be clear that any answer to an unjustified question, however the answer is phrased, is ambiguous in its nature in that it may in reality merely refuse to give what the inquirer has asked. To an illegitimate question any possible answer, contrary to the tenor of the words used in the answer, may be nothing but a refusal of the correct answer.

\section{Situation Ethics}

ScIENTIFIC ethics has scarcely coped with the preoccupations of so-called situation ethics. Situation ethics asserts that the moral judgment of an act 
can be given only in the concrete, particular situation; and that a moral judgment in terms of a general, abstract law, which is valid forever, is impossible. According to this doctrine, ethics ceases to be universally reasonable or capable of being objectified.

The basis for this approach is the following misunderstanding. It is thought that the principles of traditional ethics entail substantive statements and moral qualifications which are then universally applied to particular cases. In fact, this appearance is given as long as the negative laws (You shall not kill, You shall not speak an untruth) are not formally understood as prohibitions of what is the direct causation or permission of any given physical evil not justified by a commensurate reason. In this approach the distinction between physical and moral evil is obscured. Situation ethics then develops, not unmasking this error, although refusing to accept its consequences.

A moral judgment is naturally possible only when in a concrete act it is established whether the reason for the act is commensurate or not. On that depends whether the cause or permission of the associated physical evil is indirect, or direct and thus morally bad. With this determination the core of truth in situation ethics is taken into account without destroying the foundation for an objective morality. The answer to the question whether the reason for an act is commensurate or not depends on rigorous objective criteria and not on merely subjective or even imaginary good intention.

But another endeavor of saving the core of truth in situation ethics is erroneous. This is the distinction made between the specific and the individual lawfulness of an act. For example, according to this distinction, an act of marital intercourse without love is lawful according to its finis operis and so is in its species unobjectionable, although it lacks individual lawfulness which is determined by the finis operantis. Here there recurs in more subtle form the false distinction between the mere externals of an act as the finis operis and the inner intention as the finis operantis which $I$ have already criticized. The finis operis of any act is definable only in relation to an individual intention. An act is only morally good if its reason is commensurate; conversely it is only bad if the reason of the act is not commensurate. A marital act completed with external correctness, but not intended as the expression of personal love, is already bad in its finis operis. A special individual ethics is superfluous, because all true ethics is individual.

In response to what I published earlier on the principle of double effect, several critics raised the objection that my thesis served the cause of ethical relativism. This objection is unjust. In what $I$ have asserted up to this point, I have attempted to demonstrate that the fundamental insights of traditional ethics show that an act is morally bad if it implies in the last analysis a self- 
contradiction, and thus become unreasonable. This criterion for malum intrinsecum amounts to a universal, unconditional, objective and nonrelative rule. An immoral act is the seeking of any value in the short run while in its total existential reality the act destroys the value. The justness of this criterion cannot be denied by anyone who defends an objective ethics. I believe that this criterion is precise and not manipulable in any way, and that in using it I am a clear opponent of situation ethics. But how could my reflections have given the impression of ethical relativism? The chief reason seems to be that my critics did not sufficiently observe that the concept of a commensurate reason must be understood differently than it is commonly and inexactly understood. It is not my meaning that any act at all is permissible as long as there is a "serious reason" for it. Such a conclusion would indeed be the most evil form of ethical relativism. But a commensurate reason in my thesis is not the same as a serious reason.

A second cause for misunderstanding has been that it is assumed that certain acts like murder, unchastity, hatred of God, etc., are morally evil in advance, so that there is nothing more to prove. This is indeed just and true. If it is once established that the act is murder, then it is established that the act is morally evil. I put the question at an essentially earlier point: How can it be recognized that an act is murder? To do this, the physical fact which could be observed in a photograph does not suffice. As Thomas puts it, "Moral acts are defined by what is intended in them," or by what is directly willed in them..$^{20}$ I have sought to establish that the concept "direct" correlates with the concept "commensurate reason." If the concept "direct" is understood in the sense of direct causality or direct attention of the person who is acting, then my thesis is understood in a false sense. It would be the worst relativism if it were seriously asserted that the moral qualification of an act depends on whether or not the person acting concentrates his attention on the good intention.

In one sense, however, I plead for a kind of objective relativism in ethics. I think that there are no prefabricated judgments which can be made, but that the judgment of conscience depends on what a particular event is in reality. Whether, for example, particular behavior is hatred of God cannot be known in advance; it requires examination. It may be that the hatred is directed to a false image of God which the person refuses to serve. Similarly, a fool observing the killing of an aggressor could say, "You shall not kill," and be filled with the prideful consciousness that he spoke his verdict on behalf of the unchangeable and absolute moral law. He would still have to be told that the killing was not a direct killing in the sense of the commandment.

${ }^{20}$ See supra note 3. 


\section{Probabilism}

IN OUR discussion of the distinction between affirmative and negative laws of nature we already saw that what is fundamental is the affirmative obligation to realize in the best possible way all the values of creation. At the second level and only as it contradicts its own end is the direct permission or causing of an evil forbidden. The negative laws are applications of the affirmative laws in particular cases. Based on an understanding of this relationship probabilism asserts that one may not prevent an act which is possibly good, for the simple reason that one is not sure whether in fact it is good. As long as one is not sure that an act is morally bad, it is established that it is perhaps morally good and the fulfillment of the affirmative obligation to realize the good may be found in it. Because of the priority of the affirmative obligation to the good, it would be in the last analysis a lack of responsibility if such an act were impeded. The tutiorism which is opposed to probabilism is like the conduct of the servant entrusted with the talent who, for fear of losing it, buried it and so made no profit.

The moral system of probabilism already contains the principle of double effect as I have explained it. The simplest example is the one I have already often cited of a medical decision to be made. The doctor is obliged to determine as far as possible whether the therapy he plans is in fact the best possible; but a decision can be so pressing that he cannot wait long. The patient would be dead before the doctor reached the theoretically best medication in the books. If he could know in advance what would be the best possible measure, he would be obliged to apply it to the exclusion of all other methods. But in the actual situation because of the time pressure, the doctor is bound to put aside the achievement of ideal knowledge and is permitted to use the solution for the problem which has apparently the least risk and offers a probability of success. Concretely, he then acts in what is the best possible way considering the matter in its entirety. Care for the health of his patient would not be a commensurate reason which would justify him in letting time elapse while he pursued a long investigation. Such behavior would not be responsible. True responsibility is always a function of the best possible choice in terms of the interrelated whole.

A more general statement is necessary in this connection. In most manuals the principle of double effect is explained in such a way that it concerns only the eventual permissibility of permitting or causing a physical evil in the sense that the act is not expressly forbidden. Exceptions which are justified by commensurate reasons are not, in fact, something indifferent (a human act is never indifferent), but are positively good. They are the observance of an 
affirmative law which requires the seeking of a determinate value in the best possible way. Every act in which any value is sought in a way corresponding to its existential entirety is eo ipso morally good.

My interpretation of commensurate reason shows that someone can be so obliged in given circumstances to the causing or permitting of an evil that there is scarcely any other choice for him. This is the case where any other act would involve the violation of a negative law. For example, in the case of catastrophe the rescue of human lives is to be preferred to the salvaging of valuable goods, unless these on the whole will contribute to the saving of a greater number of human lives.

\section{Contraception}

MY INTERPRETATION of the principle of double effect may also contribute to the solution of the question, so controverted today, as to whether any form of contraception is permissible. The contribution will consist above all in a correct formulation of the question itself. In this section I will assume the results reached above, especially the definition of the concepts "direct" and "commensurate reason." Whoever reads what follows without reference to these conclusions and therefore with an inexact understanding of these concepts, runs the danger of misunderstanding the meaning of my assertions.

The teaching of the Church has been expressed as follows by Pius XI: any form of contraception in any way is immoral, just as lying, theft, and murder are immoral. It is asked today if this principle is truly general without exceptions. The more severe moralists hold that a modification of the prohibition is excluded because the Church would have to admit that it had erred on a fundamental question. Their opponents believe that this is not a question of infallible teaching and that new arguments which have developed require reconsideration of the doctrine. These opponents would admit that in certain cases contraception is permissible. The two approaches stand in irreconcilable opposition.

The insolubility produced by the problematic seems to me a sign that the question has been put in a false way. The parties to the discussion seem to take for granted a single concept of contraception derived from the encyclical Casti connubii of Pius XI: Contraception is said to be present when the conjugal act, which by its nature is directed to the procreation of offspring, is deprived of this natural meaning and power by intention (de industria). It is evident that not even the most weighty ground (nulla profecto ratio ne gravissima quidem) can effect that such an act against nature, which is evil 
in itself, be permitted. ${ }^{21}$ This apparently clear and precise determination of the concept is not inadequate or false on more exact examination, but is ambiguous.

That a marital act lose its procreative power is a purely physical evil which does not constitute a human act without further content. Thus Piux XI's definition of the concept in reference to immoral contraception notes that this act is done intentionally, de industria. In this concept lies the whole ambiguity. Is de industria meant as intentional in a psychological or in a moral sense? Let us recall again the example of the medically necessary amputation of a limb. Psychologically the doctor has the removal of the limb in mind. One can say in a psychological sense that he in fact de industria removes the limb from the body. But in a moral sense it is his intention to carry out a justified operation. Morally the act is not the removal of the limb but a healing intervention. In a moral sense the act can be justified by a commensurate reason, and the premoral, psychological action is beyond intention; the doctor's moral intention is to remove a once useful member of the body only insofar as it is an obstacle to health. If an act has a commensurate reason, the latter prevents evil from being willed directly or de industria in the moral sense, so that what psychological attention may be concentrated on is in the moral sense beyond intention, praeter intentionem. In other words, if the expression de industria used by Pius XI is understood in a moral sense, it is demonstrated according to the logic of its use that it is completely the same as the fundamental moral concepts "direct" or "formal" or "in intention," which we have already shown must be conjugated with the concept of commensurate reason.

Like all the negative laws, the prohibition of contraception means the direct permission or causing of something which must be considered in some respect a physical evil even if it appears worth being sought in some other respect. By direct is meant a causing or permission without a commensurate reason. In a case where there is a commensurate reason for the prevention of pregnancy, the moral content of the act is not the fact of contraception but the nature of the commensurate reason. Naturally in making this determination, an absolute distinction must be observed between "commensurate" and "serious." Pius XI says with complete correctness that, however serious the reason, it cannot make an act right if it is against nature in the moral sense; the

21 Pius XI, Casti connubii, Acta Apostolrcae sedis (hereafter AAS) (1930) 22:559: "At nulla profecto ratio, ne gravissima quidem, efficere potest, ut, quod intrinsece est contra naturam, id cum natura congruens et honestum fiat. Cum autem actus coniugii suapte natura proli generandae sit destinatus, qui, in eo exercendo, naturali hac eum vi atque virtute de industria destituunt, contra naturam agunt et turpe quid atque intrinsece inhonestum operantur." 
same conclusion is reached in terms of my analysis where a commensurate reason is lacking.

In ethics, care must be taken not to identify the physical or psychological order directly with the moral order. A physical evil may be caused or permitted and willed in a psychological sense, and yet the act is not necessarily a moral evil. It is a moral evil if the act has no commensurate reason but in its existential entirety contradicts the value sought. It then becomes in a moral sense contrary to nature. It can be objected that for an act contrary to nature there is never a reason which can be considered commensurate. But a conclusion as to commensurate reason logically precedes the determination that the act is contrary to nature. The objection runs counter to my assertion that the contrariness to the nature of an act is only recognized when its reason is not commensurate - that is, when between the act and its proper reason in terms of the horizon of the entire reality there is a contradiction which shows that the act is in the last analysis counterproductive.

In ethical discussions a distinction must be made between contraception in its moral sense as a prevention of pregnancy not justified by a commensurate reason and the premoral concept of actual prevention of a pregnancy. The second meaning does not yet in a moral sense belong to the finis operis of the act. If the concept of contraception in the statement of Pius XI is understood in its moral sense, his judgment is correct and by definition permits no modification. An act which is not founded on a commensurate reason is evil and remains evil because it is a self-contradiction and in the last analysis unreasonable, and it is then to be designated according to the evil physically caused by it -in this case according to the prevention of pregnancy as contraception.

If de industria is understood not in a moral, but in a psychological sense, then the judgment of Pius XI is incomprehensible and meaningless as it gives a moral meaning to a fact understood in a premoral sense. This would be roughly like determining the color of an object from its weight. On this level the discussion naturally reaches no conclusion. As long as the distinct meanings of de industria are not separated from each other, every statement must remain ambiguous even if it is believed to be clear and even if it is solemnly asserted by ecclesiastical authority.

What I have said up to now on contraception has been of an entirely formal character. I have not asserted what would be a commensurate reason because of which the prevention of a pregnancy willed in a psychological sense would remain beyond moral intention. But, fundamentally, to give such a reason would be to yield to another false framing of the question which has been seriously harmful to the discussion. A catalog of commensurate reasons 
is expected in terms of which the act for all time could be regarded as permissible, and it is assumed that there would be no need to consider further such permissible behavior. These expectations are deceptive. A list of reasons which might be composed, whether they are commensurate or not, cannot be definitively established in advance. What is at issue is a concept which depends on a relation.

The permissibility of an act, moreover, does not mean that it is permissible for all time. If a doctor uses a medicine with concomitant evil result, he remains obliged to use it as long as there is no better means, but he is also obliged to seek better solutions. Our case is similar. If what is in fact contraceptive conduct in the premoral sense is justified by a commensurate reason so that it is not an act of contraception in the moral sense, this does not mean that this reason will remain commensurate forever. There is a fundamental obligation to seek a solution for the problem which in the achieving of the values sought accepts in exchange the respectively least evil possible within the entire range of possibilities.

Many moralists content themselves in their argument with a pure proof of physical evil. They confuse the physical and the moral sense of contrariness to nature. This is as though the killing of an aggressor in a case of necessity were identified with killing in a moral sense. It is, to be sure, true that contrariness to nature in a moral sense has a relation to a physical evil which can be defined in a physical sense as contrary to nature; but moral evil comes about only through permission or causing of physical evil without commensurate reason. But this physical evil is not as such a moral evil. The same moralists found the permission of periodic continence on the logically insuffcient claim that periodic continence is not an active attack on procreation although in fact a choice of times for intercourse is a pure activity. In fact if periodic continence were practiced without commensurate reason it would not be other than impermissible contraception. This is plain from the text of Pius XII.22

${ }^{22}$ Cf. Pius XII, Allocution to the Catholic Society of Italian Midwives, October 29, 1951, AAS (1951) 43:846:

. . sottrarsi sempre e deliberatamente, senza un grave motivo, al suo primario dovere, sarebbe un peccare contro il senso stesso della vita coniugale.

Da quella prestazione positiva obbligatoria possono esimere, anche per lungo tempo, anzi per l'intera durata del matrimonio, seri motivi, come quelli che si hanno non di rado nella cosiddetta "indicazione" medica, eugenica, economica e sociale. Da ciò consegue che l'osservanza dei tempi infecondi pud essere lecita sotto l'aspetto morale; e nelle condizioni menzionate è realmente tale. Se però non vi sono, secondo un giudizio ragionevole ed equo, simili gravi ragioni personali o derivanti dalle circostanze esteriori, la volontà di evitare abitualmente la fecondita della loro unione, pur continuando a soddisfare pienamente la loro sensualita, non 
The criterion of commensurate reason means that the value whose achievement is realizable only by contraceptive measures in a premoral sense may not in the last analysis be contradicted by these measures by preventing in the long run the highest possible realization of this very value with the smallest possible evil. To prove that a particular act is contraceptive in the moral sense it must be shown that the act in the last analysis does not serve the end of preservation and deepening marital love, but in the long run subverts it.

If it is argued in accordance with scholastic ethics that the foundation of the prohibition of contraception is that the marital act is directed by its nature to the procreation of offspring, this argument is correct only if it is understood in a moral sense. The objective of the procreation of offspring is to be sought in a way commensurate to the objective and not actually subversive of it. It is conceivable that a marital act may lead to irresponsible procreation. Such an act would be a sin both against the expected child and against the children in existence whose appropriate education might not be further provided for. In this moral sense the act would be one hostile to children, an act which could be recognized as a misuse of marriage although physiologically everything appeared to be in order. It would appear that this act was in reality deprived of its natural direction to the procreation of offspring, because there would be no correspondence between the act and its end in the final analysis for the moral judgment which must be made in terms of the whole reality.

In this article directed to principles it is not possible for me to enter into further detail. But the following consequences seem valid. If someone may not reasonably be responsible for another pregnancy, the use of periodic continence, where it is not impossible because of external circumstances, seems in the usual case to best correspond to the social and human character of the marital encounter. With adequate motivation it may serve to increase mutual love. ${ }^{23}$ Where periodic continence is objectively impossible, the question is posed whether other ways may be used. These means are to be judged as to whether or not they contradict the highest possible realization of the desired value on the whole. If, for example, a man without conscience compelled his wife against her will to have marital intercourse, the wife would have an evident right to use the necessary means to prevent a pregnancy for which she cannot take the responsibility. As a wife she would not have to use

può derivare che da un falso apprezzamento della vita e da motivi estranei alle rette norme etiche.

The expression "serious motive" is somewhat inexact. The real meaning is that of a commensurate reason as in the passage of Pius XII in the Allocution to the International Society of Hematologists, Sept. 12, 1958, AAS '(1958) 50:736.

${ }^{23}$ Cf. C. Rendu, La régulation des naissances dans le cadre familial et chrétien, 87 NoUvelle ReVUe thÉologiQue 606-31 (1965). 
force against her husband. Her conduct would have nothing in common with forbidden contraception in a moral sense. It would be a scandalous mistake if I should be accused because of this position of having abandoned the "hard but healthy Catholic teaching."

\section{Conclusion}

The principle of double effect brings into usage a criterion which is implied in every decision of conscience. That an act is good means that a commensurate reason is recognized as present. Conversely, in an immoral act a lack of a commensurate reason is recognized - that is, in terms of the whole reality the act in its existential character directly contradicts the very value which is intended to be sought. A short-term, particular realization of a value is sought at the price of a greater loss for the same value as a whole. This fact is not always clear in advance because a looking back towards the horizon of reality is necessary. The task of scientific moral theology is to prove in behavior which is condemned as immoral that it contradicts the very value which is expressly sought. ${ }^{24}$ It must be cautioned that the reason for an act can prove to be commensurate only if the whole horizon is considered and not some particular aspect. Conscience has to do with the whole.

24 The Editor, whom I thank for the translation of my article, has asked me to answer this question: Does the principle work also in the sexual area? Take the hypothetical case often used of a woman who is asked to commit adultery in order that her children may be rescued from a concentration camp. If her objective is the saving of the children, is her act contradictory to this objective? Or if a woman for whom prostitution is the only way to keep from starving, is she not like the man in extreme necessity who steals? Why is her act any more adultery than his act is theft?

I would reply first that the difficulty is by no means special to the sexual area. We have the same problem in every kind of extortion or blackmail. For example, someone may be threatened with death if he refuses to take part in the falsification of a document.

The question must be answered in relation to the whole context. Does life or freedom have any value if in the end one is forced to give up all human rights and in principle be exposed to every extortion? This would be in contradiction to the very values of life and freedom. For extortion always works after the pattern of the salami, one slice of which is taken after the other: it is a menace not only for a part but also for the whole.

As for the woman who believes that prostitution is the only way to keep from starving, she is in reality also the victim of extortion. By acceding to an unjust extortion one can never really save anything in the long run. 